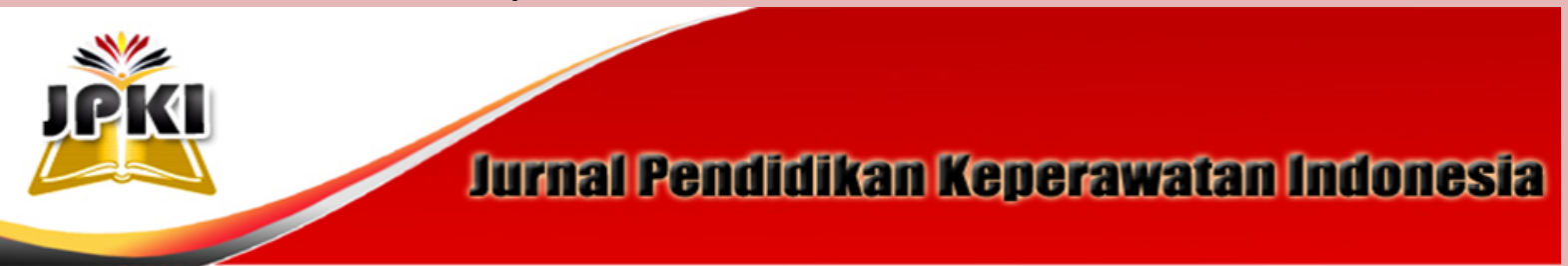

Journal homepage : http://ejournal.upi.edu/index.php/JPKI

\title{
PENGETAHUAN SISWA KELAS XI TENTANG PENYAKIT MENULAR SEKSUAL
}

\author{
Upik Rahmi $^{1}$, Kiki Gustini ${ }^{2}$, Asih Purwandari Wahyoe Puspita ${ }^{3}$ \\ Prodi DIII Keperawatan FPOK Universitas Pendidikan Indonesia \\ Email : upikrahmi@upi.edu
}

\begin{abstract}
ABSTRAK
Prevalensi PMS di negara berkembang jauh lebih tinggi dibandingkan dengan di negara maju. Usia remaja (15 - 24 tahun) merupakan $25 \%$ dari semua populasi yang aktif secara seksual, tetapi memberikan kontribusi hampir 50\% dari semua kasus PMS. Di Indonesia, berdasarkan Laporan Survei Terpadu dan Biologis Perilaku (STBP) oleh Kementrian Kesehatan RI (2011), prevalensi penyakit menular seksual (PMS) pada tahun 2011 dimana infeksi gonore dan klamidia sebesar $179 \%$ dan sifilis sebesar $44 \%$. Tujuan penelitian ini untuk mengetahui pengetahuan siswa kelas XI tentang penyakit menular seksual. Penelitian ini menggunakan metode deskriptif kuantitatif. Penelitian ini dilaksanakan di SMA Negeri 24 Bandung pada tanggal 4, 5, 8, 9 dan 11 Juni 2015 dengan jumlah populasi 359 orang serta jumlah sampel 190 orang. Pengambilan sampel menggunakan random sampling. Instrumen yang digunakan kuesioner. Hasil penelitian ini menunjukkan pengetahuan siswa kelas XI tentang Penyakit Menular Seksual di SMA diperoleh 119 orang (62,63\%) pengetahuan cukup 59 orang $(31,05 \%)$ pengetahuan kurang 12 orang $(6,32 \%)$. Kesimpulan dari penelitian ini adalah pengetahuan siswa kelas XI tentang penyakit menular seksual di SMA Negeri 24 Bandung adalah cukup 119 orang $(62,63 \%)$. Oleh karena itu peneliti merekomendasikan agar petugas kesehatan dapat lebih aktif lagi dalam memberikan penyuluhan tentang sistem reproduksi khususnya mengenai penyakit menular seksual di lingkungan sekolah.
\end{abstract}

Kata kunci : Pengetahuan, Remaja, Penyakit Menular Seksual

\section{ABSTRACT}

The prevalence of Sexually Transmitted Disease (STD) in developing countries is higher than in advanced countries. The adolescence (15-24 years old) contributes for $25 \%$ to all sexually active population, but contributes 50\% to all STD cases. According to Report of Integrated and Biologic Behavior Survey conducted by Health Ministry of Indonesian Republic (2011), the prevalence of STD in Indonesia in 2011 shows that gonorrhea and Chlamydia infection is 179\% and syphilis is 44\%. This study aims at discovering XI grade students of 24 Senior High School Bandung's knowledge about STD. It is conducted using descriptive quantitative study in 4, 5, 8, 9 and 11 June 2015, and involved 359 population and 190 samples. Simple random sampling was used as the technique and 
closed questionnaire was used as the instrument. The findings of the study show that most XI grade students of 24 Senior High School Bandung (119 respondents) have adequate knowledge about STD (62.63\%); next, 59 respondents (31.05\%) have low knowledge about STD; and 12 respondents (6.23\%) have good knowledge about STD. To conclude, the XI grade students of 24 Senior High School Bandung's knowledge about STD is adequate. Therefore, the health professionals are suggested to actively conduct more counseling about reproduction system, especially about STD, in school settings.

Keywords: Knowledge, Adolescence, Sexually Transmitted Disease (STD)

\section{PENDAHULUAN}

Penyakit menular seksual (PMS) adalah infeksi yang disebabkan oleh bakteri, virus, parasit atau jamur, yang penularannya terutama melalui hubungan seksual dari seseorang yang terinfeksi kepada mitra seksualnya. Penyakit Menular Seksual (PMS) merupakan salah satu dari sepuluh penyebab pertama penyakit yang tidak menyenangkan pada dewasa muda laki- laki dan penyebab kedua terbesar pada dewasa muda perempuan di negara berkembang (Sarwono, 2011).

Menurut World Health Organization (WHO, 2011) sebanyak 70\% pasien wanita dan beberapa pasien pria yang terinfeksi gonore atau klamidia mempunyai gejala yang asimptomatik. Antara 10\% - 40\% dari wanita yang menderita infeksi klamidia yang tidak tertangani akan berkembang menjadi pelvic inflammatory disease. Penyakit menular seksual juga merupakan penyebab infertilitas yang tersering, terutama pada wanita.

Angka kejadian PMS dari 340 juta kasus baru yang dapat disembuhkan (sifilis, gonore, infeksi klamidia, dan infeksi trikomonas) terjadi setiap tahunnya pada laki-laki dan perempuan usia 15- 49 tahun. Secara epidemiologi penyakit ini tersebar di seluruh dunia, angka kejadian paling tinggi tercatat di Asia Selatan dan Asia Tenggara, diikuti Afrika bagian Sahara, Amerika Latin, dan Karibean. Di Amerika, jumlah wanita yang menderita infeksi klamidial 3 kali lebih tinggi dari laki- laki. Dari seluruh wanita yang menderita infeksi klamidial, golongan umur yang memberikan kontribusi yang besar ialah umur 15-24 tahun (Centers for Disease Control and Prevention (CDC), 2008).

Prevalensi PMS di negara berkembang jauh lebih tinggi dibandingkan dengan di negara maju. Pada perempuan hamil di dunia, angka kejadian gonore 10 15 kali lebih tinggi, infeksi klamidia $2-3$ kali lebih tinggi, dan sifilis $10-100$ kali lebih tinggi jika dibandingkan dengan angka kejadiannya pada perempuan hamil di negara industri. Pada usia remaja (15 - 24 tahun) merupakan $25 \%$ dari semua populasi yang aktif secara seksual, tetapi memberikan kontribusi hampir 50\% dari semua kasus PMS baru yang didapat. Kasus-kasus PMS yang terdeteksi hanya menggambarkan 50\% - 80\% dari semua kasus PMS yang ada di Amerika. Ini mencerminkan keterbatasan "screening" dan rendahnya pemberitaan akan PMS (Sarwono, 2011).

Di Indonesia, berdasarkan Laporan Survei Terpadu dan Biologis Perilaku (STBP) oleh Kementrian Kesehatan RI (2011), prevalensi penyakit menular seksual 
(PMS) pada tahun 2011 dimana infeksi gonore dan klamidia sebesar $179 \%$ dan sifilis sebesar $44 \%$. Pada kasus Human immunodeficiency virus (HIV) dan Acquired immunodeficiency syndrome (AIDS) selama delapan tahun terakhir mulai dari tahun 2005 - 2012 menunjukkan adanya peningkatan. Kasus baru infeksi HIV meningkat dari 859 kasus pada 2005 menjadi 21.511 kasus di tahun 2012. Sedangkan kasus baru AIDS meningkat dari 2.639 kasus pada tahun 2005 menjadi 5.686 kasus pada tahun 2012 (http://www.depkes.go.id).

Kasus PMS di Jawa Barat pada tahun 2001 - 2011 sebanyak 19.769 kasus, dimana diantaranya diketahui bahwa kasus gonore (GO) dan sifilis sebanyak 2.189 orang dan kasus HIV/AIDS 14.934 kasus. Sedangkan di Kota Bandung diketahui bahwa kasus PMS dari tahun 2007 - 2011 sebanyak 10.956 kasus, dimana kasus HIV/AIDS di daerah Bandung pada tahun 2011 mencapai 2.541 orang (Dinas Sosial Pemerintah Provinsi Jawa Barat, 2011).

Kota Bandung merupakan kota besar oleh karenanya, Kota Bandung tidak lepas dari permasalahan penyebaran penyakit menular seksual. Angka perkembangan penyakit menular seksual di Kota Bandung tahun 2008 terdapat 1.336 kasus PMS dan pada tahun 2009 mengalami peningkatan dengan jumlah 1.777 kasus. Terjadi penurunan angka kejadian PMS pada tahun 2010 yaitu sebanyak 1.115 kasus. Penyakit menular seksual di Kota Bandung pada tahun 2012 terdapat 1.419 kasus dan semuanya telah ditangani. Meski demikian, bila dibandingkan tahun 2011 lalu terdapat peningkatan jumlah kasus PMS pada tahun 2012, karena jumlah kasus PMS pada tahun 2011 yaitu sebanyak 1.278 kasus PMS. Penyakit menular seksual telah menjadi masalah tersendiri bagi pemerintah (Profil Kesehatan Kota Bandung, 2012).

Menurut WHO, masa remaja adalah masa peralihan dari masa kanak-kanak menuju masa dewasa, di mana pada masa itu terjadi pertumbuhan yang pesat termasuk fungsi reproduksi sehingga mempengaruhi terjadinya perubahan-perubahan perkembangan, baik fisik, mental, maupun peran sosial. Pergaulan remaja saat ini perlu mendapat sorotan yang utama, karena pada masa sekarang pergaulan remaja sangat mengkhawatirkan dikarenakan perkembangan arus moderenisasi yang mendunia serta menipisnya moral serta keimanan seseorang khususnya remaja pada saat ini. Pergaulan remaja saat ini sangat mengkhawatirkan, ini dapat dilihat dari beberapa hal yakni tingginya angka pemakaian narkoba di kalangan remaja, dan adanya seks bebas di kalangan remaja di luar nikah (Yudrik Jahja, 2012).

Data Survei Kesehatan Reproduksi Remaja Indonesia terakhir Badan Koordinasi Keluarga Berencana Nasional (BKKBN) menyebutkan sebanyak 5.912 wanita di umur 15 - 19 tahun secara nasional pernah melakukan hubungan seksual. Sedangkan pria di usia yang sama berjumlah 6.578 , atau $3,7 \%$ pernah melakukan hubungan seks. Tidak adanya mata pelajaran yang secara khusus yang mengajarkan dan memberikan informasi bagi murid SMA, juga menjadi salah satu penyebab tingginya angka kejadian penyakit menular seksual di kalangan remaja. Hal ini mungkin disebabkan masih kurangnya penyuluhanpenyuluhan yang dilakukan oleh pemerintah dan badan-badan kesehatan lainnya (Surjadi, dkk., 2002:35 dalam Intan Kumalasari dan Iwan Andhyantoro, 2012). 
Pengetahuan (knowledge) merupakan hasil tahu dari manusia terhadap sesuatu, atau segala perbuatan dari manusia untuk memahami suatu objek tertentu. Pengetahuan dapat berwujud barang-barang baik lewat indera maupun lewat akal, dapat pula objek yang dipahami oleh manusia berbentuk ideal atau bersangkutan dengan masalah kejiwaan. Tingginya angka kejadian penyakit menular seksual di kalangan remaja terutama wanita, merupakan bukti bahwa masih rendahnya pengetahuan remaja akan penyakit menular seksual. Wanita dalam hal ini sering menjadi korban dari penyakit menular seksual (Notoatmodjo, 2013).

Dari hasil studi pendahuluan yang dilakukan dengan metode wawancara pada remaja sebanyak sepuluh orang responden di SMA 24 Bandung, didapatkan data bahwa delapan orang dari responden belum mengetahui tentang penyakit menular seksual. Berdasarkan latar belakang diatas, penulis tertarik untuk melakukan penelitian mengenai gambaran pengetahuan remaja tentang penyakit menular seksual di SMA 24 Bandung karena menurut Wakil Kepala sekolah dan Guru BK SMA 24 Bandung, bahwa di sekolah tersebut belum pernah di lakukan penyuluhan atau pendidikan kesehatan terutama tentang penyakit menular seksual. Pendidikan kesehatan mengenai sistem reproduksi khususnya pendidikan kesehatan tentang penyakit menular seksual bermanfaat sebagai langkah preventif untuk mengurangi angka kejadian PMS di usia remaja sekolah dan dapat meningkatkan kesehatan reproduksi remaja.

\section{METODE}

Desain penelitian yang digunakan pada penelitian ini merupakan penelitian deskriptif. Penelitian deskriptif didefinisikan suatu penelitian yang dilakukan untuk mendeskripsikan atau menggambarkan suatu fenomena yang terjadi di dalam masyarakat (Notoatmodjo, 2010). Deskriptif kuantitatif adalah penelitian yang dilakukan dengan tujuan untuk membuat gambaran atau deskripsi suatu keadaan secara objektif. Metode ini digunakan untuk memecahkan atau menjawab permasalahan yang sedang dihadapi pada situasi sekarang atau yang sedang terjadi (Notoatmodjo, 2010). Kuantitatif adalah data yang berbentuk angka atau data yang diangkakan (Sugiyono, 2011).

Responden yang terlibat dalam penelitian ini adalah siswa siswi kelas XI SMA Negeri 24 Bandung yang terbagi dalam sepuluh kelas yaitu delapan kelas Matematika dan Ilmu Alam (MIA) dan dua kelas Ilmu Ilmu Sosial (IIS). Populasi pada penelitian ini adalah seluruh siswa siswi kelas XI di SMA 24 Bandung yang berjumlah 359 orang yang terbagi dalam sepuluh kelas yaitu delapan kelas MIA dan dua kelas IIS. Sample pada penelitian ini adalah sebagian siswa siswi kelas XI MIA dan IIS di SMA Negeri 24 Bandung dengan jumlah sampel 190 orang. Cara pengambilan sampel ini menggunakan teknik simple random sampling yaitu hakikat dari pengambilan sampel secara acak sederhana adalah bahwa setiap anggota atau unit dari populasi mempunyai kesempatan yang sama untuk diseleksi sebagai sampel. Apabila besarnya sampel diinginkan itu berbedabeda, maka besarnya kesempatan bagi setiap satuan elementer untuk terpilih pun berbedabeda. Teknik pengambilan sampel secara acak sederhana ini dibedakan menjadi dua cara, yaitu dengan mengundi anggota populasi (lottery technique) atau teknik 
undian, dan dengan menggunakan tabel bilangan atau angka acak (random number) (Notoatmodjo, 2010). Dalam penelitian ini, peneliti menggunakan teknik pengambilan sampel secara acak sederhana dengan cara undian.

Instrumen penelitian yang digunakan pada penelitian ini adalah kuesioner. Dalam penelitian ini peneliti menggunakan kuesioner tertutup. Kuesioner ini telah dibuat oleh peneliti sebelumnya yaitu Rahmawati (2012) dengan menggunakan skala guttman kemudian dimodifikasi oleh peneliti. Skala guttman merupakan skala yang bersifat tegas dan konsisten dengan memberikan jawaban yang tegas seperti jawaban dari pertanyaan/ pernyataan : ya dan tidak, positif dan negatif, setuju dan tidak setuju, benar dan salah. Skala Guttman ini pada umumnya dibuat seperti checklist dengan interpretasi penilaian, apabila skor benar nilainya 1 dan apabila salah nilainya 0 dan analisisnya dapat dilakukan seperti skala Likert (Hidayat, 2011).

Kuesioner dalam penelitian ini berbentuk pertanyaan dimana dalam pertanyaan tersebut disediakan pilihan jawaban "benar" atau "salah" dan responden diminta memilih satu jawaban tersebut. Pertanyaan (+) jika benar bernilai 1, jika salah bernilai 0 pertanyaan (-) jika benar bernilai 0 , jika salah bernilai 1 . Kuisioner yang akan digunakan dalam penelitian terlebih dahulu dilakukan uji validitas dan reliabilitas dengan karakteristik yang sejenis di luar lokasi penelitian. Uji coba instrumen dalam penelitian ini dilaksanakan pada tanggal 18 Mei 2015 pada 30 orang responden di SMA Negeri 26 Bandung.

Berdasarkan uji coba validitas yang dilakukan di SMA Negeri 26 Bandung dengan data sebanyak 30 orang responden dengan 35 soal. Perhitungan dilakukan dengan menggunakan program perangkat dikomputer di dapat keseluruhan nomor valid karena nilai $r_{\text {hitung }}>r_{\text {tabel }}(0,636)$ namun setelah dilakukan perhitungan ulang dengan menghapus pertanyaan yang mendapat tanda negatif di dapatkan hasil 26 pertanyaan valid karena nilai $r_{\text {hitung }}>r_{\text {tabel }}(0,770-0,777)$, sehingga dari 35 pertanyaan lima pertanyaan di hapus yaitu pertanyaan nomor 5, 6, 8, 11, 34 dari daftar pertanyaan karena $r_{\text {hitung }}<r_{\text {tabel }}$ $<0,361$ dan empat pertanyaan lainnya yaitu pertanyaan nomor $1,2,8,10$ di perbaiki redaksinya dan mendapat persetujuan pembimbing karena empat pertanyaan tersebut mewakili setiap indikator sehingga kuesioner ini dapat digunakan untuk penelitian ini. Uji coba reliabilitas dari 30 orang responden dengan 35 soal di dapatkan $\mathrm{r}_{\text {hitung }}$ lebih besar dari alpha cronbach yaitu $0,772>(0,7)$ sehingga kuisioner dikatakan reliable. Instrumen ini terdiri dari 30 pertanyaan yang terdiri dari indikator pengertian PMS, tanda dan gejala, jenis PMS, cara pencegahan, cara penularan dan pengobatan.

Analisa data yang digunakan dalam penelitian ini adalah analisis deskriptif yang merupakan suatu prosedur pengolahan data dengan menggambarkan dan meringkas data dengan cara ilmiah dalam bentuk tabel atau grafik. Analisis deskriptif berfungsi meringkas, mengklasifikasikan, dan menyajikan data (Sugiyono, 2011). Analisis secara diskriptif ini nantinya menghasilkan distribusi dan persentase dari setiap variabel, dan disajikan dalam bentuk narasi, tabel dan diagram.

Hasil analisis data akan disajikan dalam bentuk tabel distribusi frekuensi dan persentase. Adapun data yang disampaikan adalah tabel distribusi frekuensi karakteristik, distribusi frekuensi 
pengetahuan siswa siswi kelas XI tentang PMS yang disajikan dalam bentuk tabel dan daigram, dan perolehan nilai hasil pengetahuan siswa siswi kelas XI tentang PMS di SMA Negeri 24 Bandung berdasarkan indikator.

\section{HASIL}

1. Distribusi Frekuensi Responden Berdasarkan Karakteristik Pada Siswa Siswi Kelas XI SMA Negeri 24 Bandung

\begin{tabular}{|l|c|c|}
\hline Karakteristik & F & $(\%)$ \\
\hline Usia & & \\
\hline 15 tahun & 13 & 6,84 \\
\hline 16 tahun & 78 & 41,05 \\
\hline 17 tahun & 99 & 52,11 \\
\hline Jenis Kelamin & & \\
\hline Laki-laki & 104 & 54,74 \\
\hline Perempuan & 86 & 45,26 \\
\hline Total & 190 & 100,00 \\
\hline Sumber : Data Primer
\end{tabular}

Sumber : Data Primer, Juni 2015

Berdasarkan data statistik dari tabel di atas diperoleh hasil untuk karakteristik responden berdasarkan usia yang mendominasi adalah usia 17 tahun sebanyak 99 orang $(52,11 \%)$, usia 15 tahun sebanyak 13 orang $(6,84 \%)$, dan usia 16 tahun sebanyak 78 orang $(41,05 \%)$. Sedangkan untuk karakteristik jenis kelamin didominasi oleh jenis kelamin laki-laki sebanyak 104 orang $(54,74 \%)$, dan jenis kelamin perempuan sebanyak 86 orang $(45,26 \%)$.

2 Distribusi Frekuensi Gambaran Pengetahuan Remaja Kelas XI Tentang Penyakit Menular Seksual di SMA Negeri 24 Bandung.

\begin{tabular}{|l|c|c|}
\hline Kategori & Frekuensi & $(\mathbf{\%})$ \\
\hline Baik & 12 & 6,32 \\
\hline Cukup & 119 & 62,63 \\
\hline Kurang & 59 & 31,05 \\
\hline
\end{tabular}

\begin{tabular}{|l|c|c|}
\hline Total & 190 & 100,00 \\
\hline Sumber : Data Primer, Juni 2015 &
\end{tabular}

Untuk hasil yang lebih rinci disajikan dalam bentuk diagram batang sebagai berikut :

Sumber : Data Primer, Juni 2015

Berdasarkan diagram diatas diperoleh hasil 119 orang $(62,63 \%)$ dari 190 orang responden memiliki pengetahuan cukup mengenai penyakit menular seksual, 59 orang $(31,05 \%)$ memiliki pengetahuan kurang mengenai penyakit menular seksual, dan sebanyak 12 orang $(6,32 \%)$ memiliki pengetahuan baik mengenai penyakit menular seksual.

Untuk setiap perolehan nilai hasil Pengetahuan Remaja Kelas XI Tentang Penyakit Menular Seksual di SMA Negeri 24 Bandung Berdasarkan Indikator diperoleh hasil sebagai berikut yang disajikan dalam bentuk tabel berikut.

3. Distribusi Frekuensi Perolehan Nilai Hasil Pengetahuan Remaja Kelas XI Tentang Penyakit Menular Seksual di SMA Negeri 24 Bandung Berdasarkan Indikator

\begin{tabular}{|l|r|r|r|r|r|r|}
\hline \multirow{2}{*}{ Indikator } & \multicolumn{2}{|c|}{ Baik } & \multicolumn{2}{l|}{ Cukup } & \multicolumn{2}{l|}{ Kurang } \\
\cline { 2 - 7 } & $\mathbf{f}$ & $\%$ & $\mathbf{f}$ & $\%$ & f & \% \\
\hline $\begin{array}{l}\text { Pengertian } \\
\text { PMS }\end{array}$ & 60 & 31,58 & 112 & 58,95 & 18 & 9,47 \\
\hline $\begin{array}{l}\text { Tanda } \\
\text { Gejala PMS }\end{array}$ & 120 & 63,16 & 43 & 22,63 & 27 & 14,21 \\
\hline Jenis PMS & 6 & 3,16 & 55 & 28,95 & 129 & 67,89 \\
\hline $\begin{array}{l}\text { Cara } \\
\text { Pencegahan } \\
\text { PMS }\end{array}$ & 43 & 22,63 & 78 & 41,05 & 69 & 36,32 \\
\hline $\begin{array}{l}\text { Cara } \\
\text { Penularan } \\
\text { PMS }\end{array}$ & 22 & 11,58 & 74 & 38,95 & 94 & 49,47 \\
\hline $\begin{array}{l}\text { Pengobatan } \\
\text { PMS }\end{array}$ & 33 & 17,37 & 75 & 39,47 & 82 & 43,16 \\
\hline
\end{tabular}


\begin{tabular}{|l|l|l|l|l|l|l|}
\hline Total & 190 & 100 & 190 & 100 & 190 & 100 \\
\hline
\end{tabular}

Sumber : Data Primer, Juni 2015

Berdasarkan tabel diatas diperoleh hasil bahwa nilai rata-rata setiap siswa siswi untuk indikator pertanyaan pengertian PMS, tanda dan gejala, dan cara pencegahan dikatakan sudah memiliki pengetahuan cukup. Sedangkan untuk pengetahuan mengenai jenis PMS, cara penularan dan pengobatan setiap siswa siswi dapat dikatakan memiliki pengetahuan kurang. Jika dilihat dari hasil perolehan dari setiap indikator para siswa siswi banyak terkecoh pada indikator jenis PMS terutama pada pertanyaan nomor 11 - 15 sebagian besar responden masih menjawab dengan salah sehingga diperoleh hasil 129 orang $(67,89 \%)$ dari 190 orang responden untuk indikator pertanyaan jenis PMS memiliki pengetahuan kurang mengenai penyakit menular seksual, untuk indikator cara penularan terdapat 94 $(49,47 \%)$ orang responden dapat dikatakan memiliki pengetahuan kurang, dan untuk indikator pengobatan terdapat $82(43,16 \%)$ orang responden memiliki pengetahuan kurang mengenai penyakit menular seksual.

\section{PEMBAHASAN}

Hasil penelitian menununjukkan karakteristik usia responden berada pada rentang usia 15 - 17 tahun. Usia terbanyak dalam penelitian ini adalah usia 17 tahun sebanyak 99 orang $(52,11 \%)$. Menurut Sarwono (2011) ada tiga tahap perkembangan remaja dalam proses penyesuaian diri menuju dewasa yaitu masa remaja awal (early adolescence) usia 10 - 12 tahun, remaja madya (middle adolescence) usia 13 - 15 tahun, dan masa remaja akhir (late adolescence) usia 16 - 19 tahun. Berdasarkan tahap perkembangan remaja usia responden berada pada usia remaja akhir. Remaja pada usia ini berada pada masa pendidikan sekolah menengah atas (SMA). Menurut Notoatmodjo (2010) usia mempengaruhi daya tangkap dan pola pikir seseorang, semakin bertambah usia akan semakin berkembang pula daya tangkap dan pola pikirannya sehingga pengetahuan yang diperolehnya semakin membaik, tingkat kematangan seseorang akan lebih tinggi pada saat berfikir. Pada usia tahap ini $(16-19$ tahun) yaitu remaja akhir akan lebih berperan aktif dalam masyarakat dan kehidupan sosial, serta lebih banyak melakukan persiapan demi suksesnya upaya menyesuaikan diri menuju usia tua.

Hasil penelitian menunjukkan bahwa responden mayoritas berjenis kelamin lakilaki yaitu 104 orang responden $(54,74 \%)$ sedangkan perempuan berjumlah 86 orang responden (45,26\%). Menurut Hanifah (2007) gender menentukan bagaimana dan apa yang harus diketahui oleh laki-laki dan perempuan mengenai masalah seksualitas, termasuk perilaku seksual, kehamilan, penyakit menular seksual. Konstruksi sosial mengenai atribut dan peran feminin ideal menekankan bahwa ketidaktahuan seksual, keperawanan, dan ketidaktahuan perempuan mengenai masalah seksual merupakan tanda kesucian sehingga dikatakan laki-laki mengetahui masalah seksualitas dari pada perempuan, karena perempuan dianggap lebih pasif sedangkan laiki-laki lebih aktif dalam mencari informasi mengenai seksualitas.

Berdasarkan hasil penelitian yang dilakukan pengetahuan siswa siswi kelas XI tentang penyakit menular seksual menunjukkan hasil bahwa kategori pengetahuan tertinggi siswa siswi yaitu kategori cukup sebanyak 119 orang responden $(62,63 \%)$, sebanyak 59 orang 
responden $(31,05 \%)$ memiliki pengetahuan kurang dan sebanyak 12 orang responden $(6,32 \%)$ memiliki pengetahuan baik. Penelitian ini sejalan dengan penelitian sebelumnya yang dilakukan oleh Rahmawati (2012) dengan hasil penelitian mayoritas adalah cukup, yaitu kategori baik 3 orang responden (10\%), untuk kategori cukup sebanyak 23 orang responden (77\%), dan untuk kartegori kurang 4 responden (13\%).

Berdasarkan hasil penelitian sebagian besar responden memiliki pengetahuan berkategori cukup hal ini dikarenakan sebagian dari responden sudah mendapat mata pelajaran biologi meskipun tidak secara menyeluruh menerangkan mengenai PMS, serta media massa atau informasi dan teknologi yang pada zaman sekarang semakin mudah untuk diakses untuk mendapatkan informasi apapun yang kita ingin dapatkan termasuk informasi mengenai PMS. Hal ini sesuai dengan teori Notoatmodjo (2013), dimana berbagai bentuk media massa seperti televisi, radio, surat kabar, majalah, media massa dan lainlain mempunyai pengaruh besar terhadap pembentukan opini dan kepercayaan orang. Dalam penyampaian informasi sebagai tugas pokoknya, media massa membawa pula pesan-pesan yang berisi sugesti yang dapat mengarahkan opini seseorang. Adanya informasi baru mengenai suatu hal memberikan landasan kognitif baru bagi terbentuknya pengetahuan terhadap hal tersebut.

Hasil penelitian berdasarkan indikator pengertian PMS didapatkan hasil 112 orang responden $(58,95 \%)$ memiliki pengetahuan cukup. Pada indikator ini sebagian besar responden dapat menjawab pertanyaan. Pengetian Penyakit menular seksual (PMS) adalah infeksi yang disebabkan oleh bakteri, virus, parasit atau jamur, yang penularannya terutama melalui hubungan seksual dari seseorang yang terinfeksi kepada mitra seksualnya. Infeksi menular seksual merupakan salah satu penyebab infeksi saluran reproduksi (ISR). Tidak semua PMS menyebabkan ISR, dan sebaliknya tidak semua ISR disebabkan PMS (Sarwono, 2011).

Hasil yang diperoleh dari indikator tanda dan gejala didapatkan hasil sebagian besar responden $63,16 \%$ dapat menjawab pertanyaan dengan benar. Tanda dan gejala penyakit menular seksual pada laki-laki dan pada perempuan biasanya dapat ditandai dengan gejala seperti lesi pada bagian vulva atau penis, gatal atau seperti terbakar, terasa nyeri atau seperti terbakar pada saat akan berkemih (Reeder et al, 2011).

Hasil yang diperoleh dari indikator jenis PMS didapat hasil 129 orang responden $(67,89 \%)$ sangat kurang untuk menjawab karena hampir seluruh responden menjawab pertanyaan dengan salah. Sebagian besar mengetahui mengenai jenis PMS tapi tidak mengetahui mengenai penyebab PMS untuk jenis Trikomoniasis yang disebabkan oleh Trichomonas vaginalis, Sifilis yang disebabkan oleh Treponema pallidium, Vaginosis disebabkan oleh Gardnerella vaginalis, Herpes Simpleks disebabkan oleh Virus Herpes Simpleks, Ulkus Mole disebabkan oleh Streptobacillus ducrey (Haemophilus ducreyi) (Sarwono, 2011).

Hasil penelitian berdasarkan indikator pencegahan di dapat hasil hampir setengah responden 78 orang $(41,05 \%)$ memiliki pengetahuan cukup. Hampir setengah responden dapat menjawab pertanyaan mengenai pencegahan penyakit menular seksual. Siswa siswi menjawab pencegahan PMS dengan tidak bergontaganti pasangan dan memakai kondom. Pencegahan PMS yaitu dengan cara 
membatasi hubungan seksual, tidak melakukan hubungan seksual apabila terdapat lesi oral atau genital, serta menggunakan kondom (Reeder et al, 2011).

$$
\text { Hasil penelitian berdasarkan }
$$

indikator cara penularan di dapat hasil 94 orang responden $(49,47 \%)$ sangat kurang untuk menjawab pertanyaan karena hampir setengah responden menjawab pertanyaan dengan salah. Hampir setengah dari responden hanya mengetahui cara penularan PMS melalui hubungan seksual secara langsung dan melalui darah. Penularan PMS selain dapat ditularkan melalui hubungan langsung juga dapat ditularkan melalui transfusi darah, saling bertukar jarum suntik pada pengguna narkoba, tertusuk jarum suntik yang tidak steril secara sengaja atau tidak sengaja, menindik telinga atau tato dengan jarum yang tidak steril, penggunaan alat pisau cukur secara bersama-sama (khususnya jika terluka dan menyisakan darah pada alat), dari ibu hamil kepada bayi (bisa terjadi saat hamil, saat melahirkan, dan saat menyusui) (Marmi 2013).

Hasil penelitian berdasarkan indikator pengobatan di dapatkan hasil 82 orang responden $(43,16 \%)$ kurang untuk menjawab pertanyaan karena hampir setengah responden menjawab salah pada indikator pengobatan. Pengobatan untuk setiap PMS berbeda-beda, cara pengobatan yang diberikan ada yang melalui oral, topikal, intramuskular, intrakutan dan sebagainya (Sarwono, 2011).

Pada indikator jenis PMS, cara penularan dan pencegahan siswa siswi memiliki pengetahuan kurang karena berdasarkan informasi yang diperoleh peneliti pada saat melakukan studi pendahuluan diperoleh data bahwa pihak sekolah belum pernah mengadakan penyuluhan atau pendidikan kesehatan tentang kesehatan reproduksi khususnya mengenai penyakit menular seksual oleh petugas kesehatan maupun instansi kesehatan lainya di sekolah. Pendidikan memengaruhi proses belajar, makin tinggi pendidikan seseorang, makin mudah orang tersebut untuk menerima informasi. Dengan pendidikan tinggi, maka seseorang akan cenderung untuk mendapatkan informasi, baik dari orang lain maupun dari media massa. Informasi yang diperoleh baik dari pendidikan formal maupun non formal dapat memberikan pengetahuan jangka pendek (Immediate impact) sehingga menghasilkan perubahan atau peningkatan pengetahuan. Berkembangnya teknologi akan menyediakan bermacam-macam media massa yang dapat memengaruhi pengetahuan masyarakat tentang inovasi baru (Notoatmodjo 2013).

\section{KESIMPULAN}

Berdasarkan hasil analisa data dan pembahasan hasil penelitian yang dilakukan oleh peneliti maka dapat diambil kesimpulan bahwa penelitain mengenai "Gambaran Pengetahuan Siswa Siswi Kelas XI Tentang Penyakit Menular Seksual di SMA Negeri 24 Bandung" berada dalam kategori hasil tertinggi adalah kategori cukup.

\section{DAFTAR PUSTAKA}

Ali, M dan Asrori, M. (2012). Psikologi remaja. Jakarta : PT Bumi Aksara.

Arikunto, S. (2010). Prosedur Penelitian Suatu Pendekatan Praktek. Jakarta :Rineka Cipta.

Baskaran, S. (2011). Tingkat Pengetahuan Mahasiswa Fakultas Kesehatan 
Masyarakat Universitas Sumatra

Tentang Infeksi Menular Seksual, (Online), Skripsi, http://repositoty.usu.ac.id/handle/1234 56789/24068. Diakses pada tanggal : 05 April 2015 (jam 16.00 WIB).

Bethsaida, J., dan Herri, Zan Pieter. (2013). Pendidikan Psikologi untuk Bidan Suatu Teori dan Terapannya. Edisi 1. Yogyakarta : Rapha Publishing.

Chuningham et al. (2012). Obsterti Williams. Jakarta : EGC.

Departemen Kesehatan RI. (2010). Riset Kesehatan Dasar Tahun 2010, (Online),

http://www.litbang.depkes.go.id/sites/d ownload/buku_laporan/lapnas_riskesd as2010/Laporan_riskesdas_2010.pdf . Diakses tanggal 30 April 2015, (jam 15.15 WIB).

Hidayat, Aziz. Alimul. (2011). Metodologi

penelitian keperawatan dan teknik analisis data. Jakarta : Salemba Medika

Jahja, Yudrik. (2012). Psikologi

Perkembangan. Edisi 2. Jakarta :

Kencana Prenada Media Group.

Kementian Kesehatan RI. (2012). Profil

Kesehatan Indonesia Tahun 2012,

(Online),

http://www.depkes.go.id/download/PR

OFIL_DATA_KESEHATAN_INDON

ESIA_TAHUN_2012.pdf. Diakses

tanggal 02 Mei 2015, (jam 14.00)

Kumalasari, I., dan Andhyantoro, I. (2012).

Kesehatan Reproduksi Untuk

Mahasiswa Kebidanan dan

Keperawatan. Jakarta: Salemba

Medika.

Marmi. (2013). Kesehatan Reproduksi.

Yogyakarta: Pustaka Pelajar

Nursalam. (2011). Konsep dan Penerapan
Metodologi Penelitian Ilmu

Keperawatan. Edisi ke-2. Jakarta :

Salemba Medika.

Notoatmodjo, Soekidjo. (2010). Metodologi Penelitian Kesehatan (Ed. Rev). Jakarta: Rineka Cipta.

Notoatmodjo, S. (2013). Metodologi Penelitian Kesehatan (Ed. Rev). Jakarta: Rineka Cipta.

Prawirohardjo, S. (2011). Ilmu Kebidanan. Jakarta : BPSJ.

Reeder et. al . (2011). Maternity Nursing : Family, Newborn, and Women's Health Care. Jakarta : EGC.

Rompas, S. (2012). Pengaruh Pendidikan Kesehatan Terhadap Tingkat Pengetahuan dan Sikap Remaja Tentang Penyakit Menular Seksual Di SMK Fajar Bolaang Mongondow Timur. (Skripsi). Studi Ilmu Keperawatan Fakultas Kedokteran, Universitas Sam Latulangi, Manado.

Rahmawati, N. (2012). Tingkat Pengetahuan Remaja Tentang Penyakit Menular Seksual Siswi Kelas XI Di SMA Batik 1 Surakarta Tahun 2012. (Online), http://stikeskusumahusada.ac.id/digilib /files/disk1/1/01-gdl-noviarahma-39-1noviara-7.pdf. Diakses pada tanggal : 10 Februari 2015 (jam 14.00 WIB).

Setiadi. (2013). Konsep dan Penulisan Riset Keperawatan. Yogyakarta: Graha Ilmu.

Sugiyono. 2010. Statistika Untuk Penelitian. Bandung : Alfa Beta. 